\title{
A Short Account of the Indians of the Issá-Japurá District (South America).
}

\section{Thomas W. Whiffen}

To cite this article: Thomas W. Whiffen (1913) A Short Account of the Indians of the Issá-Japurá District (South America)., Folklore, 24:1, 41-62, DOI: 10.1080/0015587X.1913.9719548

To link to this article: http://dx.doi.org/10.1080/0015587X.1913.9719548

曲 Published online: 06 Feb 2012.

Submit your article to this journal $\asymp$

Q

View related articles 주 


\section{A SHORT ACCOUNT OF THE INDIANS OF THE ISSÁ-JAPURÁ DISTRICT (SOUTH AMERICA).}

By CaITAin 'T. W. Whiffen, Fourteenth Hussars.

(Read at Meeting, December 18th, I9I2.)

NorTH of the main artery of the great Amazonian system, between the Rio Negro and the Napo, both of which tributaries have long been known to the traveller, trader, and missionary, lies a great stretch of virgin forest, drained by the Issa and the Japura rivers and their affluents. To the north of the Japura the watershed of an important tributary of the Negro, the Uaupes river, has also been more or less opened to European influences, but the Issá and Japurá basins remained unknown, and are to this day a veritable No-man's-land among the nations, claimed by Brazil, Peru, and Ecuador, but not administered by any : where never a king's writ can run, and where each man does what is, presumably, right in his own eyes and, frequently, egregiously wrong in his neighbour's.

The main trend of the country is a gentle slope from north-west to south-east, not sufficient to make the river currents rapid in normal conditions, though the rate of descent naturally increases greatly when flood water is coming down. Inundations are frequent, and a great one probably occurs two or three times in a century. So it is not, therefore, surprising to find that these Indians have many stories of a Great Flood.

The land between the river beds is broken by low parallel ranges of hills, densely wooded. Here and there on higher 


\section{The Indians of the Issa-Japurá District.}

ground a savannah, a natural geological outcrop, breaks the dense bush with a comparatively open space, where a totally distinct soil and flora will be found. The Boro explanation for these outcrops is that they are where Neva, the Good Spirit, spoke to the Indians when on a visit to earth, in recognition of which they are open to the sun and the sky to this day.

The soil in the forest itself is dark and damp, built up of successive layers of decayed vegetable matter. The rainfall is excessive and continual, the temperature hardly varies throughout the year, and heavy storms are frequent, especially in February and September, which roughly stand in Amazonia for the seasons designated as the Rains elsewhere.

Though the forest abounds in flower-bearing plants and trees, fruits of gay colours, birds and insects of the brightest hues, it is a place of dull and oppressive gloom, for all the life, and light, and colouring are massed overhead in the treetops, hidden from sight by a density of foliage, and an intricate tangle of creepers and parasitical growths. The effect of existence in such environment is depressing in the extreme. Everything is against progress. All makes for a dead-level resignation to an intolerable but unavoidable fate. There are no roads of communication except the waterways. Life is a ceaseless warfare with certainly-hostile nature and probably-hostile man.

These wild solitudes are inhabited by groups of Indians, as to whose origin and racial classification opinions are greatly divided. In the country now under discussion there are nine language-groups,- the Witoto, Boro, Andoke, Resigero, Muenane, Okaina or Dukaiya, Menimehe, Karahone, and Nonuya. It is with the first two, the Witoto and Boro, that we are mainly concerned.

These two language-groups occupy roughly the centre of my field of exploration, and are separated from each other by the Dukaiya-speaking tribes. The Boro tongue is more: 
unintelligible to a Witoto than the speech of a Friesland Hollander would be to a Briton from the North, and these groups differ from each other not only in linguistic but in physical details. Their order in the cultural scale approximates to the physical features and colouring of the Indians belonging to the group. The Andoke and the Boro, the better-looking, better-developed, taller, and lighter-coloured groups, are also the most intellectual. The lighter-skinned Indians look down on and despise the darker tribes, and those of the lowest grades, such as the Maku, are regarded as slave tribes by all the others. There is extreme animosity between the different groups, in addition to recurrent warfare between individual tribes of each group.

These patrilineal exogamous tribes dwell apart, and but little communication exists between even those of the same language-group. There is no organised trade, no recognised trade routes nor trade centres. An intermittent, irregular barter is carried on by individuals only. Every tribe has one, (or possibly two), maloka, a tribal house in which every member of the tribe has a right to food and lodging. Every maloka has its absolutely independent Chief, who is subservient to no higher power, answerable only to his own tribal council The maloka are built on a wooden framework, and thatched from the ridge-pole almost to the ground with layers of palm leaves. The average size of these buildings is about seventy feet in diameter, but they differ in accordance with the numbers of the tribes. They are not permanent habitations. After two or three years the maloka ceases to be weather-proof ; the soil of the plantation also is impoverished by successive cropping. No attempt to better either is made. The community merely abandons its old headquarters, and makes tracks for another site. The forest furnishes all it needs for house-building ; fresh ground is cleared for the plantation; and life continues as of old. A further reason that induces the Indian to submit to these unsettled conditions 


\section{The Indians of the Issa-Japurd District.}

is that, despite all possible caution, tracks must get worn through the bush converging on the homestead, and a path is simply an invitation to an enemy. Safety lies in isolation and secrecy, for no other attempt at defensive measures is ever made, except to dig pits in the forest avenues and arm them with poisoned stakes to trap an enemy, be it man or beast.

Inside the maloka, or tribal lodge, cornered by the four great posts that support the framework, is a clear space, which is used as a dancing ground. One end of the building is set apart for the Chief and his women; the rest of the space round the maloka, between the outer wall and the central square, is allotted to the families of the tribe: There are no partitions, but each has its fire, made of three logs set endways, and by this are slung the three family hammocks in a triangle. But, in addition to his quarters in the tribal house, any man may, if he so pleases, build himself a small dwelling in the bush. This could, however, only be done by a married man, because of the very strict line of cleavage between the work done by the men and that done by the women. In no circumstances would a man cook, plant manioc, or prepare the cassava. He is therefore dependent upon his woman for the necessaries of life.

Each community, under its independent Chief, is strictly monogamous and exogamous, for all within the maloka are held to be akin, and the only probable exception to the exogamous rule would be in the case of a Chief with no son to succeed him. He might, with tribal consent, marry his daughter to one of the household, in order thus to gain an heir. There is no head chief to unite the tribes of any language-group, and only in the most exceptional circumstances would any tribes combine even in self-defence against a common enemy.

The Chief is elected by the tribal council of warriors, assembled in tobacco palaver, the tribal parliament and 
court of law. He holds office till death, when his son, sonin-law, or adopted son would probably be elected to succeed him.

The rival authority is the medicine-man, and the amount of power exercised by either depends entirely upon their personality. The medicine-man is not a priest; he officiates for no divinity, offers no sacrifice, no prayer. It is his business to oppose magic to magic, and so protect his tribe, or his individual patients, from the ills resulting from the malevolent magic-tvorking of their enemies. But of this anon.

From first to last the Indian is hedged about by pia, (' it is so,' 'it is our custom'). Before a child's birth the mother, and after birth the father, must submit to certain definite tabus. These differ slightly among the tribes, but are similar in all essentials. The mother, for instance, must not eat paca flesh, or the child's skin will be spotted like that beast's; nor capybara, or the child will have the teeth of a rodent: in fact her diet often is restricted to cassava and such poor food as small bony fish, frogs, lizards, and little snakes. Should she give birth to twins, one will be left by her exposed in the bush, where, when her time comes, she will have retired alone, or with one other woman. If the twins were girl and boy, the girl would be killed; otherwise it would be the second, as obviously that is the one who has no business to appear on the scene. The reason averred is that only beasts have more than one at a birth, and the Indian's aversion to anything resembling the brute creation is intense. To avoid any such likeness the tribes depilate, more or less strictly, all hair but that of the head. The exception is the medicine-man, and the hairier he is the better. For the same reason they blacken the teeth.

If a child at birth were seen to be deformed or sickly, the mother, during the bath in the river which is immediately resorted to, would simply submerge it till life was extinct. 


\section{The Indians of the Issa-Japurd District.}

Should several unfortunate births occur at any time it would certainly lead to war, as the tribe would attribute the evil to the hostile magic of some foe. After bathing, the mother and infant return to the maloka, and the father retires to his hammock to play the part of interesting invalid. In no part of my district is the couvade carried out with the rigour described by Dr. Crevaux and Sir Everard im Thurn. The Boro, who are in every way more punctilious than the Witoto, observe it most strictly; but the Boro father is not put to torture. He lies in his hammock for some three weeks, and till the child's navel is healed he must not hunt, nor even touch a weapon, and must not partake of foods that were previously tabu to his wife, (that is to say, he may not eat the flesh of any hunted animal, and so must practically forego his share in the family hot-pot). The penalty for infringement of the tabu on the part of father or mother is that the infant will be either deformed or malignant. The mother goes back next day to her work in the plantation, only returning to feed the baby at night; while the father receives congratulatory visits from his friends, talks, drinks, and licks tobacco with them. Tobacco, I may note here, is never smoked by these peoples, though they quickly learnt to smoke mine. This seems a curious point, for the tribes to the north smoke the leaf in the form of cigars, and those further south use pipes. A decoction, like raw treacle in appearance, is made from the leaf, and this is licked ceremonially between friends, to ratify a contract, and in tribal palaver.

When the medicine-man has arrived, and given his opinion on the new-born infant, it will be named, on the eighth day, by the medicine-man and the family, with ceremonial tobacco taking. Boys are generally called by the name of a bird or animal, usually the name of their father's father. Girls are given the names of plants or flowers. This name is never used in speaking. Witoto men address one another as tanyabe (brother), or iero (father): Boro 
as moma. Women are grvaro (mother), tangali (sister), in Witoto ; einyo (mother), or muije (woman), in Boro. The white man may call himself or his Indian companions what he pleases. As he does not know their real names he cannot harm them by the use of fictitious ones. If he runs the risk in his own case of giving power to any hostile magic-worker to do him harm, through knowledge of the name that represents his essential ego, that is his affair. This secrecy of name applies also to the tribes. Indians call their tribe only by a word equivalent to 'our own people,' and bestow a nickname for general purposes upon their neighbours. This all makes for difficulty in the way of any classification.

The name given, the couvade period at an end, the little Indian ceases to be of any particular tribal importance for the next few years. From earliest childhood the youngsters share the lives of their parents. Nothing is hidden from boys or girls; nor is there any great ceremony over the formal admission of a youth to tribal rank. He has been taught to hunt and fish; he is allowed to attend a tribal tobacco palaver and to lick tobacco, after he has declared he will bear himself bravely. There are no such trials for the novice as the northern tribes impose in ceremonial whipping and Jurupari observances. Girls on the verge of maturity are segregated in secret lodges in the bush, in part for protective purposes, - where tribes are in the vicinity of the , raiding Andoke or other enemies, - but there is always some 'communication between the lodge and the tribal house and, when it can safely be done, the girls will be brought in for any tribal festivities. But they remain in the lodges till they are married.

The marriage ceremony is simple. A man who desires to take a wife must have won a certain reputation as a hunter, to show he could support a wlfe and family, or no girl would take him for her husband. He must clear a plot of forest land for a plantation; obtain permission from the 
girl's Chief by the present of a pot of coca and a pot of tobacco; and take to his future parents-in-law a piece of palm shingle, such as the roof is thatched with, and a section of a small tree,-symbolic proof respectively that he has either built his own house or obtained quarters in one, and has cleared a plantation. The father will produce coca and tobacco, and when they have licked this together the preliminaries are done. Two weeks later the marriage is consummated.

A man is practically free to marry according to his fancy, so long as the bride selected is not a member of his own household, nor one of a hostile tribe. Indians choose, as a rule, girls considerably younger than themselves, and the child-wife is brought up by the women of her husband's tribe until she arrives at maturity.

Unmarried women, and girl-slaves captured in war, belong to the Chief, but they are his wards, not his wives. If a man desires to marry a slave-girl, he must give a present to the Chief's wife. After marriage the girl is free.

Life is a strenuous business for all, and especially the women, for their work is continual, but the men's intermittent. Women are the cooks and the agriculturalists. Woman, the Indian says, can produce children, so it follows that she can produce manioc. Therefore no man will ever plant the manioc slips, nor prepare the cassava. His task is to fish, to hunt, and to fight.

The great event in Indian existence, the one social. function, the sole outlet for all there may be of art in the Indian nature, is the dance. Anything will serve as an excuse for such festivity, and all the energies of the tribe for days beforehand will be concentrated on the preparations. From childhood they have practised the steps, and learnt the tribal melodies. Dress on ordinary occasions is almost non-existent; the men wear only a strip of beaten barkcloth, and the women not even this; but they paint the most elaborate and brilliant designs upon their naked skins, 
especially for a dance, when they also adorn themselves with all the ornaments in their possession,-feather headdresses if they be men, beaded garlands if women, and as much in the way of necklaces, armlets, and jangling leg rattles as each can muster. This finery is brought out from the storage places on the rafters of the maloka. Though the women may not wear feathers, they fasten the white down of the currasow duck to the calves of their legs with rubber latex, or some resinous substance. This makes them look enormous, owing to the fact that they wear tight ligatures below the knee and above the ankle to swell out the muscles, after the same fashion that the men wear ligatures on the upper arm. The Indian will never part with his feather ornaments, for they are communal, not personal, possessions; and I found that they objected extremely to any attempt on my part to secure photographs of them. I have only one of a small boy, the son of a Chief, wearing his feather head-dress. He was also the only boy I ever saw wearing one, as the feathers are supposed to be from birds shot by the wearers, in the same way that the necklaces of tiger, tapir, pig, or other teeth represent the game killed by the hunter who wears them, or therewith decorates his family.

When a dance is to be given, invitations are sent round to all friendly Indians in the vicinity. A piece of tobacco folded in a palm leaf is the 'at home card' of the Indian. The summons to a dance, however, depends on no formal card. The Chief himself conveys it by means of the manguare, the great signal drums hung from the rafters of the maloka. He beats out his message in notes that travel for eight or ten miles round. These drums are constructed from two blocks of hard black wood, hollowed by means of heated stones, with a husk of purposely varying thickness to secure the range of notes. The smaller is termed the male, and the larger the female drum, and they are decorated within by designs representative of their sex. 


\section{The Indians of the Issa-Japura District.}

Then on the appointed day the guests assemble, in their best paint and ornaments. Set against the deep gloom of the forest, some two or three hundred Indians in full dress, -a shifting kaleidoscope of paint, feathers, beads, and dance rattles, with decorated dance staves and musical instruments, - the smouldering fires of the maloka stirred to a blaze, and the hot flickering of torches adding to the glow of light, the scene is indescribably bizarre. Nor is the eye alone affected. Strange and wonderful sounds torment the ear; the music of instruments never played for private amusement, only on such ceremonial occasions, (panpipes, flutes, and drums), adds volume to the stamp of the dancers' feet, the jangle of the leg-rattles, and the loud, shrill singing of the performers. The man appointed to lead the dance must be one who knows the old songs, mere strings of now unintelligible words handed down from some traditional and quite forgotten ancestors. The leader sings the solo, in a high falsetto, and the chorus, picking up their cue, repeat it with a simultaneously gradual crescendo of sound and speed.

The circumstance giving cause for the dance determines if men and women sing together or alone. All songs are sung in unison, with a drone accompaniment from those not actually articulating the words, to regular time, marked by stamping, but with no hand-clapping. The tunes are simple, and as a rule merely the repetition of a single phrase with no variations, repeated endlessly. What these mean no living Indian knows. They are the tribal songs that have always been sung, that are the only right things to sing; nor could I detect any suggestion of change or correction ever attempted or desired. There are no love, sacred, or nursery songs, and war songs are merely the chants proper for a war dance, and depend for significance on the occasion and the spirit of the dancers.

There is in this region no regular harvest time. Crops grow and ripen all the year round, irrespective of season, 
but pineapples are at their best in October, which determines the date of the special Pineapple Dance. Manioc is planted mostly just before the heaviest rainfall is expected. At these, which might be called Harvest Dances, the dancing staves are decorated with part of the plant to be honoured, a tuft of pine or a bundle of manioc leaves. The leader starts outside the maloka, probably with some fancy stepping. The dancers, in single file, each with a hand on the shoulder of the next in front, circle outside the maloka with a step described by Spruce as ' a succession of dactyls,'-Right,-left,-stamp. Right,-left,-stamp, -repeated backwards at lesser intervals. Maintaining step and time the long line enters the house, to dance round the Chief till all are assembled. Then, after a signal for silence, the Chief sings a line that gives the keynote of the occasion. The men in some cases dance in a ring, faced by a ring of women'dancers; in others women dance between the men; and, again, the men and younger girls may dance round the older women.

The Boro Manioc-gathering Dance may be taken as a typical example. The men form up into an outer circle, the women in the centre or behind the men of their choice, dancing with steps complementary to, and not identical with, the men's. The Chief starts with a question, something after this sort :-

"I am old and weak and my belly craves food, Who has sown the pika (manioc slips) in the emiye (plantation)?"

His wife answers :-

"I have sown the pika, long, long ago;

The maika is sown with young shoots."

The chorus of women join in and repeat the answer, changing the verb and pronoun to the plural.

The Chief then questions, after the same introductory line, "Who has cut the pika in the emiye?" and is answered in like manner. The song continues till the whole process 


\section{The Indians of the Issá-Japura District.}

of growing manioc and preparing cassava is described, and the meaning will gradually shift from the birth and growth of the plant to the birth of a human being, The song is interminable, and will only be concluded when the Chief cries :-

$$
\begin{aligned}
& \text { "Imine (it is good), imine, } \\
& \text { The women are good women, } \\
& \text { Imine." }
\end{aligned}
$$

The Muenane, a language-group between the Andoke and Resigero peoples, have a special Riddle Dance. This has been copied by many of their neighbours, judging from the fact that wherever it is danced the answer, if in the negative, is given in the Muenane language. The leader, a man selected for his wit, asks a riddle, probably original. The dancing chorus repeat it till the measure ends; then the questioner with a lighted torch rushes round and seeks an answer, thrusting his torch in the face of those he questions. Herewith comes the Muenane reply Jana, (I do not know). The dancer then joins the file following the originator and copying his actions, which are supposed to give the clue to the riddle, probably the name of a bird or animal, whose movements would be copied with an astonishingly adept mimicry, which is somewhat akin to certain children's games. The wit of the riddle depends on the amount of sexual suggestion that can be introduced in the reply, for these people, though strictly moral (by their own and even by our standards) in their habits, are in their most ordinary conversation what we should consider licentious in the extreme.

A dance is kept going for four or five days without cessation, and the amount of liquid consumed is amazing, though solid food is at a discount. The drinks are not alcoholic, but are made from certain fruits and appear to serve for food as well as drink. The excitement grows wilder and wilder; the noise intensifies; the breadth of suggestion in action and word increases to a degree im- 
possible to mention in detail. It would appear to be the maddest orgie of drunken abandonment, yet it never touches eroticism.

Maddest and most impressive is the dance that follows the return of the warriors from a successful fight. All the prisoners, except any young children who may safely be kept for slaves, are knocked down and killed with wooden swords, and an anthropophagous feast of vengeance follows. These Indians are cannibals, primarily, in my opinion, for purposes of continued hostility. Human flesh is only on rare occasions eaten for lack of animal food, never for gluttony, nor, so far as I could discover, with any idea that the qualities of the eaten would be absorbed by the eater. It is a purely ceremonial matter, a ritual of vengeance, in which the women have no share, except the Chief's wife, to whom the genital organs of the male victims are allotted. This is noteworthy in that such parts of any animal are on no other occasion eaten by these tribes, who consider the intestines, brains, and so forth as carrion, unfit for human consumption. At the cannibal feast only the legs, arms, and fleshy parts of the head are eaten. The teeth are carefully preserved by the slayer to make into a necklace, visible proof of his prowess and completed revenge. The skulls are dried and hung outside or on the rafters of the maloka above the drums. What is not consumed is thrown into the river, and thus carried down stream, away from the Indian Paradise, which lies far up-stream. Some tribes bury the trunk with public jeers and insults, or it is often left for the wild dogs to devour. The humerus is made into a flute. The forearm, with dried hand and contracted fingers, makes a gruesome ladle to stir the pot wherein the human flesh, cut in pieces and highly seasoned with peppers, is cooked by the old women of the tribe, what time the warriors, the gory heads of the slain on their dancing 


\section{The Indians of the Issá-Japura District.}

staves, sing, dance, and drink to a repletion relieved by vomiting, only to be indulged in again and again.

To appreciate the extent of the revenge accomplished by these anthropophagous practices it must be remembered that the Indian has an invincible hatred of all wild animals, which he looks upon as his enemies. To serve an enemy as a dead beast,- to eat him,-is the most profound insult he can offer. Moreover, the insult is carried out in further details. The teeth, though not bored as animals' would be, are made into a necklace, and they become a personal possession of the slayer. Now death to the Indian is not an end of all things. It is a transition. The dead still exist, for he sees them in his dreams; but they live in another world where everything, themselves included, is on a reduced scale. In this World of the After Life the soul requires what the body needed on earth. Mutilate the body, divorce it from all its possessions, keep essential portions of it, and a naked soul is cast forth to wander endlessly in the forest, or to go down the holes in the earth that lead to the regions of the damned. In any case the Indian's Paradise is unattainable to his enemies. In consequence of this belief in an ultramundane existence, when an Indian dies all personal properties and ornaments are buried with the body,-weapons with a man, pots and domestic articles with a woman. The corpse is wrapped in its hammock, and buried inside the maloka, below where the hammock used to hang, and a fire is kept burning by the relatives over the grave for some days. In the case of a Chief the maloka would be burnt, and the community migrate elsewhere. At the conclusion of the funeral feast everyone bathes ceremonially, for purposes of purification.

The soul of the deceased hovers near for a time, and then wanders off to the happy hunting grounds of the Good Spirit.

There is, in Indian opinion, no such thing as death from natural causes; it must be due to the malignant influence 
of an enemy, working in sickness by means of the spirits of disease, or, should the death be accidental, brought about by the inimical intent of the object responsible, inspiring that animosity. The only way to avert or overcome these magical evils is to secure the protecting counter-magic of the medicine-man. This gentleman combines with clumsy conjuring skilled ventriloquism, some degree of hypnotic power, and often a considerable knowledge of drugs. He is poison-maker to the tribe, an important post where all lethal weapons are armed with poisoned darts. Poison plays a great part in Indian affairs. The Karahone especially are famous for their knowledge of toxicology. Perhaps I should rather say notorious, witness such Indian proverbs as "Take a pine from a Karahone and die." If a case of sickness is beyond the medicine-man's skill to remedy, after he has administered a strong narcotic he will have the patient taken out into the bush, and left there under a rough shelter. No one must venture near, or death will result. If the sufferer is dead next day, it is, of course, due to the fact that someone transgressed, and either spoke to or passed him. If by any chance he should recover he will relate his dreams, and from them the medicine-man will 'divine' who was the enemy from whom the sickness emanated. Vengeance ensues.

With regard to dreams, the Indian believes that in sleep the spirit can pass out of the body by the mouth, and visit the scenes and places recalled after waking. All souls have this involuntary power of temporary migration, and some more gifted beings can exercise it voluntarily. The medicine-man is credited with this capacity, and he must employ it for the protection of the tribe. In particular he can assume the form of a jaguar. This great cat, the 'tiger' of Amazonia, is dreaded not only for its daring and ferocity, but even more because it is a magical beast. It shares the qualification with the anaconda, the yacumama, mother spirit of the waters that bars the streams 


\section{The Indians of the Issa-Japurd District.}

and gives rise to flcods. Omnivorous eater though he be, no Indian would kill the great water-snake, nor the jaguar, for food. When a child is killed by a tiger, or is lost in the bush, (taken by the tiger in Indian opinion), a tribal hunt would be organised, and the tiger-folk dealt with as human enemies would be; for they, like humans, can institute a blood feud with their enemies. The brute, if killed, would be brought back to the maloka and a feast of revenge, similar in detail to the anthropophagous orgies, would follow. Every medicine-man possesses a tiger skin in which he keeps his magic. It is never used as a covering, but the wizard is supposed to assume it when he goes forth in tiger form to work against tribal enemies.

In a sense any animal, all nature in fact, is inimical to the Indian. $\mathrm{He}$ is set in an overpowering environment. Isolated, without spur to material or intellectual progress, his surroundings assume a fearsome significance. It needs not much incentive to imagination to people the dark places of the sombre, illimitable forest with legions of threatening devils. Somewhere, above the sky which is the roof of the world, is an infinitely remote, intangible Beneficence, a Great Good Spirit, who is good for the sole reason that he is not evil. This is Neva, already mentioned as the Great Spirit who once visited earth in the guise of a man, and spoke to the Indians. The tale was told me by a Boro, but is practically the same among all these groups. But, runs the myth, one Indian displeased the Good Spirit, who thereupon told the tiger-people to be wicked, and kill the Indians who had heretofore been their brothers. Then the Good Spirit went back to his happy hunting-grounds, and was seen no more by men. Moreover, he is entirely passive. The Bad Spirit, whose kingdom lies below, is on the contrary possessed of an exceeding activity. His energies are ceaseless, and all malevolent. Both these Powers have subordinate spirits respectively good and evil. No prayer is offered to the Good, no supplication made to the Bad 
Spirit, and sacrifice is quite unknown, nor is there any attempt to placate any spirits with gifts.

There are, according to Indian belief, four kinds of spirits : the temporarily disembodied spirits of the living; the permanently disembodied of the dead; the extra-mundane spirits; and the spirits of all animate or inanimate objects. The Indian believes in a temporary transmission of soul from one body to another, for a definite purpose and time, whether the spirit be one disembodied temporarily or permanently, or whether it be extra-mundane. As for the spirit that exists in all objects, - the 'trarscendental $x$ ' is Pfleiderer's illuminating expression,-this belief is the corner-stone of the Indian magico-religious system. In no other way can he explain the occult influences that surround and oppose him. Whether, when a higher-grade spirit migrates temporarily into a lower material form, the native spirit of that form is expelled, or shares its habitation for the time being, I was not able to ascertain.

Thunder is the noise of the spirits of evil when angry, and before a thunderstorm the air is full of bad spirits, whom the medicine-man must attempt to drive away, for probably they bring sickness from some enemy, wishful to destroy the tribe. Anything abnormal or unknown is regarded with suspicion. It is far more likely to be evil than good. One of the Witoto tribes had a double-stemmed palm tree that was an object of great importance, even of veneration, though not actually of worship. The sun and moon also are regarded with veneration, but are not worshipped. The moon is the sun's wife, and is sent by him periodically to prevent the evil spirits of the bush from killing everyone when the sun has set. Little attention is paid to the stars, but a Boro told me they were the spirits of great men of his tribe.

All Indians fear darkness, for then the powers of evil are most active, and no one willingly ventures far alone after sundown, nor would one bathe without a companion. In 


\section{The Indians of the Issa-Japura District.}

the shelter of the maloka they gather around the family fires for the meal of the day, and afterwards first one and then another will tell tales far into the night.

These long rigmaroles are not easy to understand, and the variations are so many that it is difficult to ascertain if the tale is a new one or merely a fresh edition of something heard often before. Animal tales abound, stories in which the birds and beasts stand for characteristic ideas. Of the latter the following are typical:-

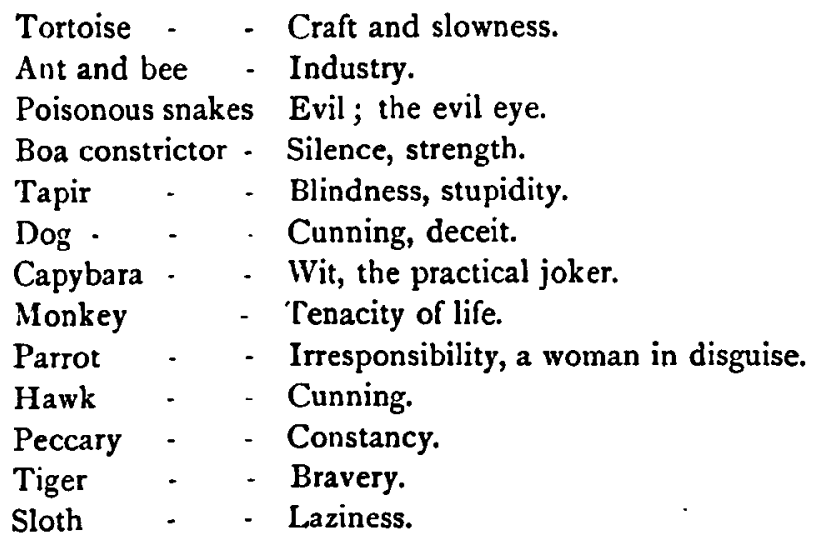

Though there are tales of bygone Chiefs of outstanding merit, relationship is only traced so far as memory serves, practically only on the father's side, for the mother, brought from another household, soon among these unsettled tribes will lose touch with her own people. There is no trace of any totemic system. Animals, I repeat, are hated enemies. I questioned a Boro tribe about one district void of habitations, and was told that the reason was as follows :-

"The Utiguene once lived there, the most powerful of tribes, but long, long ago the Chief had a daughter, ugly and birdrumped, so the medicine-man called her Kemuime, (monkey). When she was so high (five feet) she went out to pick peppers in the bush, and did not return. The tribe decided a tiger had taken her, and organised a tribal hunt, but they were attacked by 
a wicked tribe, and great numbers were killed. Long afterwards, [I am abbreviating considerably], Kemuime returned to the maloka, with her bird-rump covered with hair. The old women rubbed it with milk to remove the unsightliness. But it only grew the faster, so she was covered with leaves. She told them that a kemuime, i.e. a monkey, had seized her and carried her forcibly off to be his woman. She gave birth to twins, and buried the second, as even kemuime have but one at a birth. The child was hairy like a kemuime, with the face of a man. When she suckled him her unsightliness came. So she ran away. The tribe held a tobacco palaver, and because of the pollution, and the blood feud with the wicked tribe, and the girl's unsightliness, they determined to kill her. But she fled back to the forest, and all the kemuime came and robbed the plantation; and the lianas grew like nets, so that no man of the Utiguene could hunt, and the tribe died out."

There are also many myths connected with the discovery and cultivation of manioc, as well as of other fruits, but space forbids more than reference to them or to the numerous fables equivalent to such world-wide tales as the Lion and the Mouse, and the Hare and the Tortoise. In detail the Indian versions differ greatly from the Old World stories, but in every case the principle is identical.

The Indian has a firm belief in omens, but none of these tribes make much use of charms, though men wear bracelets of iguana skin, and children have a ring cut from the polished shell of a nut, put on the arm for lucky magic purposes. Defence lies in observation of tabu, and due heed to what is ruled good or evil; also the study of lucky and unlucky signs. I ought to mention the universal belief among these Indians in the potency of human breath as an evil-expelling agency. Much of the medicine-man's ceremonial healing consists of blowing and breathing over the patient, as well as the usual sucking out of the poison, the evil spirit that, in the guise of stick, stone, thorn, or some similar object, lurks in the flesh of the sufferer and causes 
the sickness. But others besides the medicine-man can remove evil by the breathing or sucking process. Spruce mentions Indians sucking each other's shoulders as a cure for rheumatism, and I have often known an old woman breathe over forbidden food, to remove the 'poison' and make it permissible to eat. They will breathe over a delicate child in the same way, to improve its health.

Dr. von Martius considered the savage state of the Forest Indians to be the result of degradation, a theory recently advanced with regard to these identical tribes in the Contemporary Review for September, I9I2. For my part I agree with Dr. Tylor " that Dr. Martius' deduction is the absolute reverse of the truth," 1 and regard this theory as erroneous. I saw nothing to suggest degeneration. On the contrary, it appears to me that, in spite of the awful handicap of environment, these tribes are probably evolving a higher life.

I found no traces of the existence of any submerged superior civilization, but much to show that these people have not yet emerged from practically the Stone Age. There is no metal in the country but what filters in by barter and is employed for ornaments,-mostly Peruvian and Chilian dollars and empty cartridge cases. There is also no stone. Metal tools or weapons are unknown. They have only wood, and stone axes. The latter they look upon as of almost divine origin, and have handed down, they know not from whence, generation by generation. They have not learnt to produce fire, and have no knowledge of the potter's wheel, nor of the spindle. Thread they make from palm fibre, rolled on the naked thigh. Beaten bark cloth is their only material. Ligatures are made with finger-work only, in plaiting of an extraordinary fineness. Hammocks are knotted. Baskets, mats, cassava-squeezers, and other bark-fibre articles are plaited. Yet with their primitive tools, a stone axe, wooden knife,

${ }^{2}$ Early History of Mankind, p. 139. 
The Indians of the Issa-Japura District. 6I

and capybara-tooth awl, they turn out such finely finished work as the blow-pipe, made with infinite toil and patience from laths of hard wood, strips split off the trunk of the chonta palm.

Everything points to the conclusion that these tribes found their way to the Forest in a very primitive condition. The Forest has arrested, has stunted their growth, but it has not plunged them back from later cultures to the Stone Age.

Did space permit I would greatly like to touch on the disputed question of origin. I was continually struck by the prevalence of Mongoloid traits, especially the obliquity of eye, most noticeable in the Boro, but more or less common to all the groups. Tempting parallels of custom and belief can be drawn, too, with the peoples of similar cultures to be found among the pagan races of Malaya and New Guinea. Mr. T. A. Joyce in his recent book on the Archaeology of South America repudiates the idea that contact with any Pacific cultures could have exerted permanent influence on the indigenous population. Against any such supposition he advances the argument that there are no linguistic traces of Polynesian or Melanesian dialects to be found, and also avers that, to quote his own words, - "Any people arriving on the Pacific coast must have been skilled seamen, and it seems incredible that, after settling, they should have proceeded immediately to forget their craft, especially as their chief source of nourishment must have been the sea. Yet through the whole of the coast of South America nothing but the most primitive form of raft was found, and it appears that sails were entirely unknown south of Tumbez." 2 But unwritten languages are surely a parlous guide. The tongues of Amazonia, at least, are still in constant flux. Yesterday's word may have other meaning to-day, and be changed out of all recognition to-morrow. The second

\footnotetext{
'South American Archaeology, p. 190.
} 
62 The Indians of the Issa-Japura District.

argument can hardly be pressed in face of Dr. Rivers' Dundee paper on the Decadence of Useful Arts. In any case it is a fascinating subject, and, so far as the Indians of the Issá-Japurá district are concerned, not one that can be set aside for a more convenient indefinite future to solve. Their solitudes have been broken. There was only piá, our custom, to keep tribal law and legend from an obliteration no research can remedy. An alien culture,-I cannot call it a higher one,- has intruded. Even now the Boro and Witoto as I knew them are exceedingly hard to find. It may be that I was the first and last white man to meet them unaffected by outside influences.

ThOMAS WhIFFEN. 